Gut, 1973, 14, 25-29

\title{
Zollinger-Ellison syndrome type 1: clinical and pathological correlations in a case
}

\author{
D. J. COWLEY, I. W. DYMOCK, B. E. BOYES, R. Y. WILSON, B. H. STAGG, \\ M. R. LEWIN, JUliA M. POLAK, AND A. G. E. PEARSE
}

From the Departments of Surgery and Medicine, University Hospital of South Manchester, the Department of Surgery, University College Hospital Medical School, London, and the Department of Histochemistry, Royal Postgraduate Medical School, London

SUMMARY Some patients with the Zollinger-Ellison syndrome appear to have hypergastrinaemia and hyperplasia of the antral G cells but no tumour. This subgroup has been classified as ZollingerEllison syndrome type 1 . We have treated such a patient by vagotomy and antrectomy, the fasting plasma gastrin and acid secretion subsequently returning to normal.

A 17-year-old male had a four-year history of duodenal ulcer. Gastric secretion tests showed acid hypersecretion. Fasting plasma gastrin was $8350 \mathrm{pg} / \mathrm{ml}$ (normal 50-170 pg/ml). At laparotomy duodenal ulceration was confirmed but no pancreatic or other tumours were found. Truncal vagotomy and antrectomy was performed with distal pancreatectomy. Immunofluorescent staining showed hyperplasia of $\mathrm{G}$ cells in the resected antrum but a normal pancreas and duodenum.

Six months after operation he was symptom free and acid secretion was reduced by $92 \%$. The fasting plasma gastrin at two months was $<50 \mathrm{pg} / \mathrm{ml}$.

These findings suggest that type 1 Zollinger-Ellison syndrome may be a clinical entity.

The chief criteria for diagnosis of the syndrome first described by Zollinger and Ellison (1955) were, until recently, the presence of a fulminating peptic ulcer diathesis, hypersecretion of gastric acid, and a gastrinsecreting islet cell tumour of the pancreas. The accepted treatment is total gastrectomy, radical pancreatectomy, or a combination of the two. It is now apparent that some patients with the ZollingerEllison syndrome do not have a pancreatic tumour, and in some instances immunofluorescence staining of the gastric antrum after total gastrectomy has revealed marked hyperplasia of the antral $G$ cells (Polak, Stagg, and Pearse, 1972).

\section{Case Report}

The patient, a 17-year-old male plastics worker, was first referred to the gastroenterology clinic of the University Hospital of South Manchester in January 1971. He gave a four-year history of severe epigastric pain after meals relieved by milk and antacids. He had no other symptoms of note and his bowel habit was normal. His paternal grandfather and one 18-

Received for publication 16 October 1972. year-old cousin had a history of peptic ulcer. Barium meal examination revealed a large ulcer crater in the first part of the duodenum accompanied by coarse gastric and duodenal mucosal folds. The stomach was noted to contain excess resting juice.

His symptoms increased during the following year despite a full antacid regime and were not relieved by a five-week course of Duogastrone begun in November 1971. He was admitted to hospital in January 1972 for further investigation and for possible surgical treatment.

\section{PREOPERATIVE INVESTIGATIONS}

Gastroduodenoscopy and a repeat barium meal examination confirmed the presence of a chronic duodenal ulcer.

Gastric acid secretion tests were performed on three separate occasions (Baron, 1970) and the results are summarized in the Table. Both the basal acidity and basal acid output were very high in the first two tests although lower in the third test. When considered with the severity of his symptoms the diagnosis of Zollinger-Ellison syndrome seemed likely.

Fasting plasma gastrin levels were determined by radioimmunoassay, using antibodies to synthetic. 


\begin{tabular}{lccc}
\hline $\begin{array}{l}\text { Preoperative Gastric Secretion } \\
\text { Test }\end{array}$ & Test & & \\
\cline { 2 - 4 } & First & Second & Third \\
\hline Fasting volume (ml) & 185 & 100 & 110 \\
Maximum basal acidity (m-equiv/1) & 92 & 90 & 68 \\
Basal acid output (m-equiv/hr) & $13 \cdot 6$ & $12 \cdot 8$ & $5 \cdot 3$ \\
PAO (pentagastrin) (m-equiv/hr) & 47.8 & - & 52.0 \\
PAO (insulin) (m-equiv/hr) & - & $33 \cdot 4$ & - \\
\hline
\end{tabular}

Table Preoperative tests of gastric acid secretion

${ }^{1}$ Note that the basal acidity and output was considerably lower in the third test.

human gastrin I (Temperley and Stagg, 1972). The level was grossly raised at $8350 \mathrm{pg} / \mathrm{ml}$ (normal range $50-170 \mathrm{pg} / \mathrm{ml})$. Tests were then performed on a separate day to determine the effect of intragastric neutralization with sodium bicarbonate on plasma gastrin levels (Hansky, Korman, Cowley, and Baron, 1971). The fasting plasma gastrin levels were again high at 7550 and $8300 \mathrm{pg} / \mathrm{ml}$. During intragastric neutralization the level was unchanged at $8300 \mathrm{pg} / \mathrm{ml}$.

A pancreatic scan with ${ }^{75}$ Se-selenomethionine showed a normal and uniform uptake of isotope in the area of the pancreas. Selective coeliac axis and superior mesenteric arteriography demonstrated no abnormality of the pancreatic circulation. Radiographs of the pituitary fossa and of both hands were normal.

A full blood count, blood urea and electrolytes, and liver function tests were all normal. The serum calcium ranged from 10.5 to $10.9 \mathrm{mg} / 100 \mathrm{ml}$, and an oral glucose tolerance test showed a normal curve. Three-day faecal fat excretion averaged $2.8 \mathrm{~g} /$ day. The urinary catecholamine output was normal at $0.4 \mathrm{mg} / 24$ hours.

A diagnosis of the Zollinger-Ellison syndrome with hypergastrinaemia arising from an unknown source was made and laparotomy was arranged.

OPERATIVE FINDINGS AND PROCEDURE At operation in March 1972 the first part of the duodenum was found to be grossly deformed, with active anterior and posterior ulceration. The entire pancreas was palpated carefully but no nodules or other abnormalities were found. Two enlarged suprapancreatic lymph nodes were removed which on frozen section microscopy were normal. As no tumour had been found it seemed possible that the antrum was the source of the hypergastrinaemia, and in view of the patient's age a truncal vagotomy and antrectomy with Billroth I anastomosis was performed in preference to a total gastrectomy. In addition, the body and tail of the pancreas and the spleen were resected. Portions of different areas of the resected antrum and pancreas were immediately placed in fixatives for subsequent histochemical studies.

\section{HISTOLOGY}

With routine staining techniques the mucosa of the resected antrum was normal. Removal of antral tissue was complete. Sections of the pancreas failed to reveal any evidence of an islet cell tumour or of islet cell hyperplasia.

\section{HISTOCHEMICAL STUDIES}

\section{Immunofluorescence}

Small pieces of pancreatic tissue were quenched in Arcton (Freon) 22 at $-158^{\circ} \mathrm{C}$ and subsequently $5 \mu \mathrm{m}$ cryostat sections were prepared.

Samples of gastric mucosa were fixed at $4^{\circ} \mathrm{C}$ in $4 \%$ methanol-free formaldehyde (MFF) for three to six days. They were then dehydrated, cleared, and embedded in $56^{\circ} \mathrm{C} \mathrm{mp}$ paraffin wax. Methanol-free formaldehyde was prepared according to directions given by Polak, Bussolati, and Pearse (1971). Sections were cut at $5 \mu \mathrm{m}$ and picked up from water on glycerin-albumin-coated slides. They were dried at $37^{\circ} \mathrm{C}$ for 24 hours and dewaxed in light petroleum.

An indirect method was employed (Coons, Leduc, and Connolly, 1955) using rabbit antihuman gastrin I serum for the first layer and fluorescein-labelled goat antirabbit IgG globulin (Hyland) for the second layer. Formaldehyde-fixed, paraffin-embedded sections were used for the demonstration of $G$ cells in the antrum (Bussolati and Pearse, 1970) and unfixed cryostat sections for the demonstration of the gastrin-producing D cells of the pancreas (Greider and McGuigan, 1971).

The following controls were used: (1) antihuman gastrin with added excess of synthetic gastrin 1 followed by fluorescein-labelled antiglobulin; (2) normal rabbit serum followed by the second layer; (3) fluorescein-labelled goat antirabbit globulin alone.

Sections were examined on a Laborlux microscope fitted with a quartz-iodine lamp and also on a Zeiss (Oberkochen) standard universal microscope, fitted with HBO 200 mercury arc lamps.

Photographs were taken with an Ilford FP4 film.

Optical microscopic methods for islet cells

Small blocks of pancreas were fixed for 24 hours in formol-saline; $6 \%$ glutaraldehyde in $0.1 \mathrm{M}$ phos-

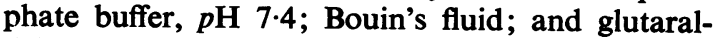
dehyde-picric acid (Solcia, Vassallo, and Capella, 1968). All blocks were subsequently washed in water, dehydrated, cleared, and embedded in $56^{\circ} \mathrm{C} \mathrm{mp}$ paraffin wax. Sections $(5 \mu \mathrm{m})$ from appropriate (correctly fixed) blocks were processed by methods 
selective for the secretory granules of pancreatic endocrine cells.

Fresh frozen cryostat sections were studied by dark-field luminescence which demonstrates pancreatic a2 (A) cells (Cavallero and Solcia, 1964).

The following staining methods were used: aldehyde fuchsin (Gomori, 1952) for islet B cell granules; phosphotungstic haematein (PTAH) (Terner, Gurland, and Gaer, 1964), the O-phthalaldehyde method (Takaya, 1970), and dark-field luminescence for A cell granules; toluidine blue metachromasia (Manocchio, 1964) for D cells; lead haematoxylin with and without prior acid treatment (Solcia, Capella, and Vassallo, 1969) for A and D cells; Grimelius (1968) silver for A cell granules. All these techniques were photographed on Ilford Pan F film.

\section{Results}

PANCREAS

The pancreatic islets were normal in number, size, and distribution. The different types of cells within the islets were present in normal proportions.

\section{Antral mucosa}

Immunofluorescence studies showed a high degree of hyperplasia of the $\mathrm{G}$ cells, localized mainly within the middle zone of the glands (Figs. 1 and 2), and was confirmed by electron microscopic studies. An interesting and unusual feature was the relative emptiness of many $\mathrm{G}$ cells (Fig. 3).

\section{Duodenal mucosa}

\section{POSTOPERATIVE COURSE AND FINDINGS}

His postoperative course was uneventful. He was discharged home well and free from dyspepsia in April 1972, and has remained symptom-free to date, having regained his preoperative weight.

Fasting plasma gastrin levels estimated on two separate days in the fourth postoperative week were less than $50 \mathrm{pg} / \mathrm{ml}$.

A gastric acid secretion test was performed 10 weeks after operation with the following results: basal acid output $0.45 \mathrm{~m}$-equiv/hour. Peak acid output to pentagastrin $4.77 \mathrm{~m}$-equiv/hour. This represented a decrease in the PAOPG of $91 \%$ compared with the preoperative value.

\section{Discussion}

Since the first description by Zollinger and Ellison (1955) of the syndrome which now bears their name, clinicians have accepted that the humoral substance (gastrin) is secreted either by a tumour, usually of

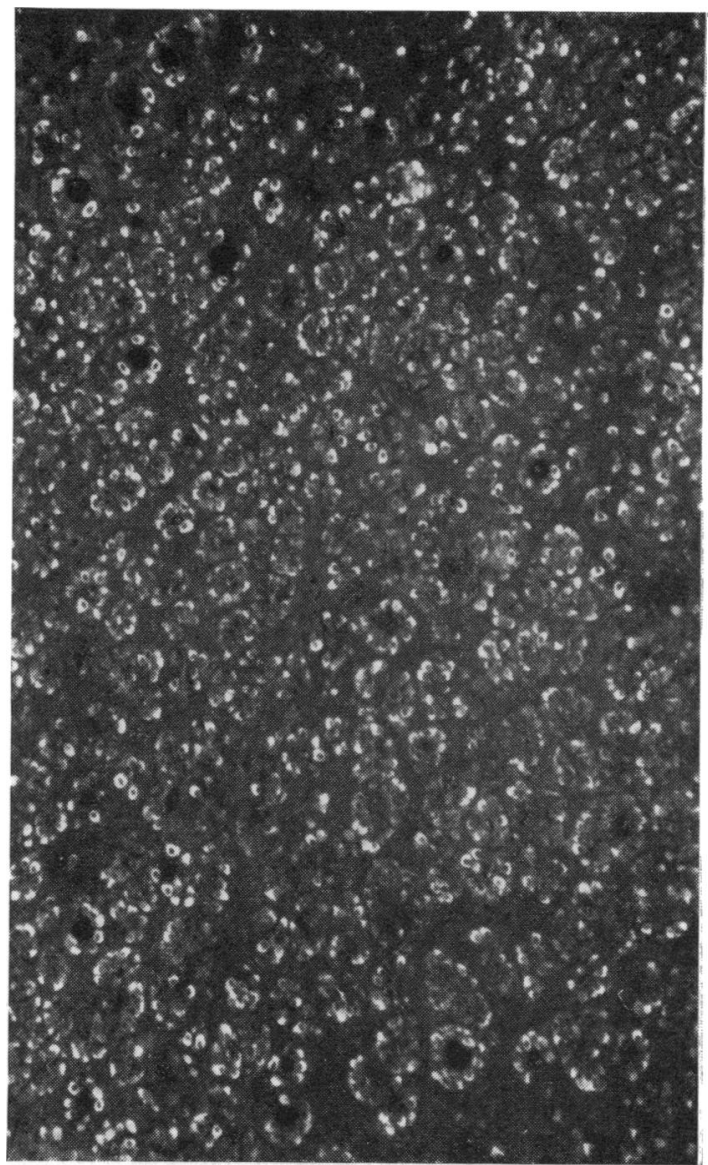

Fig. 1 Low-power view. Indirect immunofluorescence method using anti-synthetic human gastrin serum. Shows very extensive $G$ cell hyperplasia, each pyloric gland (cross section) at this level being composed almost entirely of $G$ cells. A considerable proportion of the latter are submaximally fuorescent, suggesting high gastrin output and turnover. $\times 140$

the pancreas, or by a diffuse adenomatosis of the pancreas. Recently patients with the ZollingerEllison syndrome and abnormally high levels of circulating gastrin have been studied in whom no tumour or pancreatic abnormality could be found either at operation or at necropsy. Furthermore, when the gastric antrum of these patients was studied histochemically, $G$ cells were found in numbers (up to 30 times normal) greatly in excess of those in the antrum of normal patients with duodenal ulcer. At a symposium held at Northwick Park Hospital in February 1972 it was suggested that the Zollinger-Ellison syndrome can be thus classified into two types: type 1, due to hyperplasia of the 


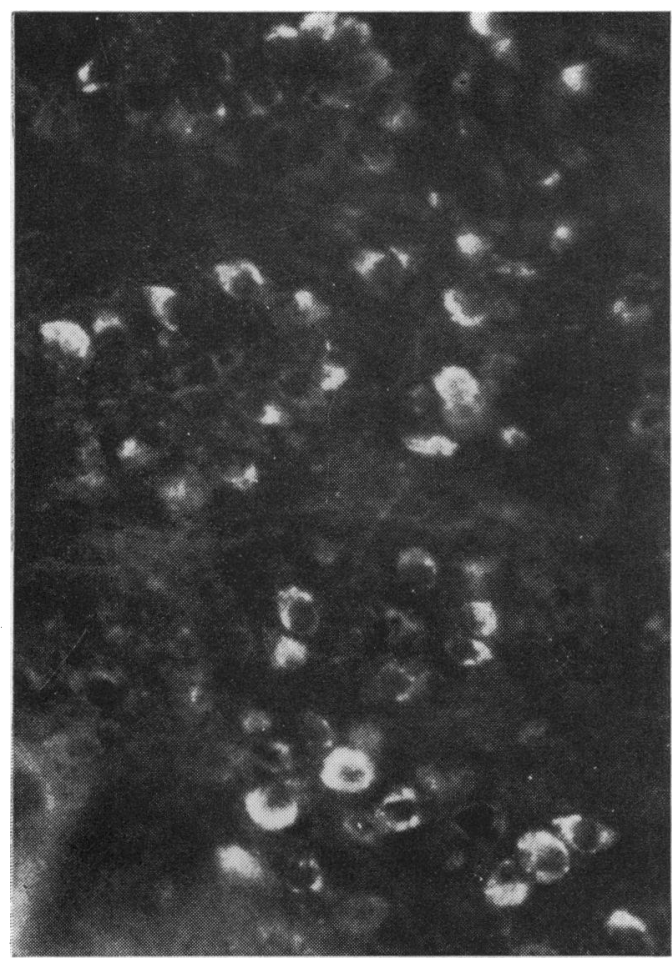

Fig. 2 High-power view. Immunofluorescence preparation. Many partly discharged $G$ cells are present. $\times 492$ antral G cells, and type 2 due to a gastrin-secreting tumour (Polak et al, 1972). These two types were regarded, in effect, as stages in the progression of the disorder. Other characteristics of the type 1 ZollingerEllison patients appeared to be that they are young, that they have a relatively short history of peptic ulcer in comparison with type 2 patients, and that they have extremely high levels of circulating gastrin.

We believe that the present patient had a type 1 Zollinger-Ellison syndrome and that the dramatic return of his fasting plasma gastrin to normal after antrectomy and vagotomy suggests that the antrum was the sole source of the hypergastrinaemia. Furthermore, the lack of effect of intragastric neutralization on this gastrin level suggests either that $\mathrm{G}$ cells were secreting maximally and thus could not respond to this increase of the antral $p \mathrm{H}$ as would be expected (Hansky et al, 1971) or that the antrum was autonomous and completely independent of the intraluminal $p \mathrm{H}$. The partial degranulation of the cells which we observed was thus possibly due to a neutralization effect.

The gastric antrum was normal on light microscopy with conventional staining and it must be emphasized that the resected pancreas was normal histologically and showed no hyperplasia of the gastrin-secreting D cells on immunofluorescence staining. The present case indicated that antrectomy and vagotomy is the treatment of choice in the type 1 ZollingerEllison syndrome in preference to the more radical

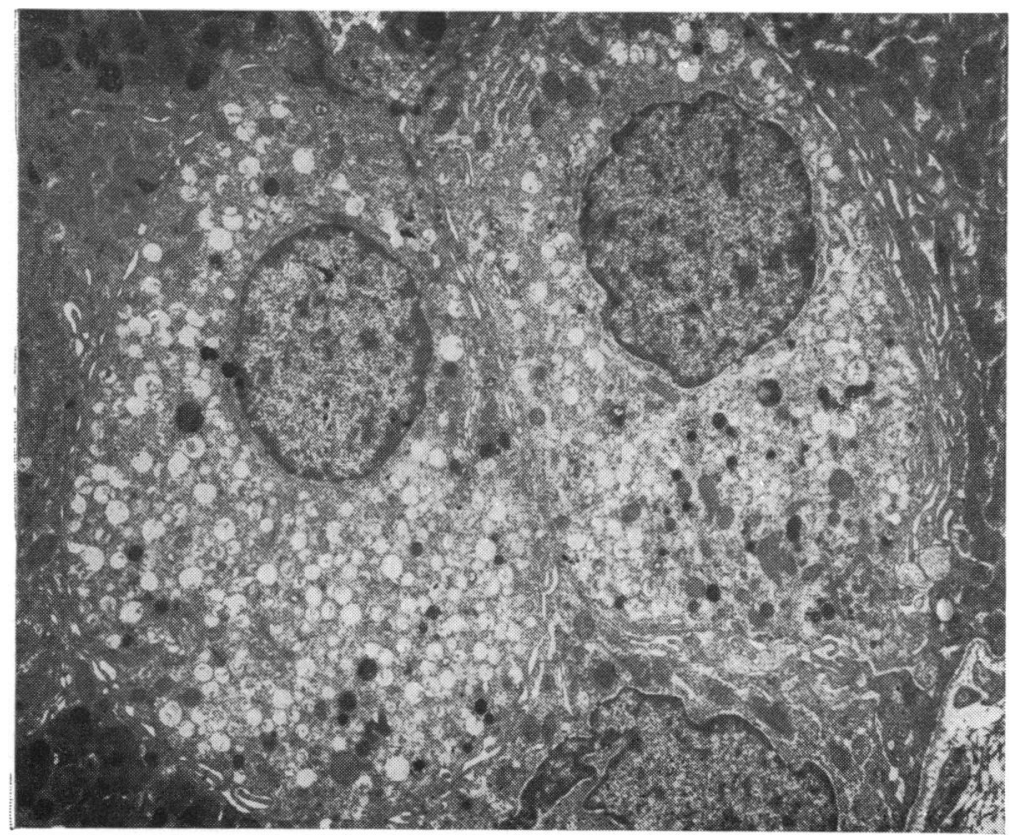

Fig. 3 Ultrastructural studies showed partly discharged $G$ cells in large numbers. $\times 5400$ 
procedure of total gastrectomy with its higher operative mortality and postoperative morbidity. However, this course must be followed with caution and we would recommend that in addition to a thorough search for tumours, the presence of microadenomata must be excluded by performing a distal pancreatectomy. Friesen (1968) has suggested that a pituitary factor is directly responsible for $G$ cell hyperplasia and for the development of tumours from pancreatic $\mathrm{G}$ cells. If his hypothesis is valid and applies to every case of the Zollinger-Ellison syndrome, it would seem likely that extragastric $G$ cells, such as those in the duodenum, and also the D cells of the pancreas, would undergo hyperplasia. They have so far failed to do so in the present patient. Nevertheless, he will obviously have to be followed up closely with regular serum gastrin estimations over the next few years before we can assume a permanent cure.

We would like to thank Mr J. B. Elder, Manchester Royal Infirmary, and Miss P. Watkins, UHSM, who performed the gastric secretion tests; Dr J. S. Whittaker of the Department of Pathology, UHSM, for histology, and Professor R. A. Sellwood for constructive criticism.

\section{References}

Baron, J. H. (1970). The clinical use of gastric function tests. Scand.J. Gastroent., 5, Suppl. 9-46.

Bussolati, G., and Pearse, A. G. E. (1970). Immunofluorescent localization of the gastrin-secreting G-cells in the pyloric antrum of the pig. Histochemie, 21, 1-4.

Cavallero, C., and Solcia, E.(1964). Cytologic and cytochemical studies on the pancreatic islets. In The Structure and Metabolism of the Pancreatic Islets, edited by S. E. Brolin, B. Hellman, and H. Knutson, pp. 83-97. Pergamon Press, Oxford.

Coons, A. H., Leduc, E. H., and Connolly, J. M. (1955). Studies on antibody production. 1. A method for the histochemical demonstration of specific antibody and its application to a study of the hyperimmune rabbit. J. exp. Med., 102, 49-60.
Friesen, S. R. (1968). A gastric factor in the pathogenesis of the Zollinger-Ellison syndrome. Ann. Surg., 168, 483-501.

Gomori, G. (1952). Microscopic Histochemistry. University of Chicago Press, Chicago.

Greider, M. H., and McGuigan, J. E. (1971). Cellular localization of gastrin in the human pancreas. Diabetes. 20, 389-396.

Grimelius, L. (1968). A silver nitrate stain for a 2 cells in human pancreatic islets. Acta Soc. Med. upsalien., 73, 243-270.

Hansky, J., Korman, M. G., Cowley, D. J., and Baron, J. H. (1971) Serum gastrin in duodenal ulcer. Part II. Effect of insulin hyperglycaemia. Gut, 12, 959-962.

Manocchio, I. (1964). The metachromatic A-cells in the pancreatic islets of dogs of different ages. In The Structure and Metabolism of the Pancreatic Islets, edited by S. E. Brolin, B. Hellman, and H. Knutson, pp. 105-116. Pergamon Press, Oxford.

Polak, J. M., Bussolati, G., and Pearse, A. G. E. (1971). Cytochemical immunofluorescence and ultrastructural investigations on the antral G-cells in hyperparathyroidism. Virchows Arch. Abt. B. Zell. path., 9, 187-197.

Polak, J. M., Stagg, B., and Pearse, A. G. E. (1972). Two types of Zollinger-Ellison syndrome. Immunofluorescent, cytochemical and ultrastructural studies of the antral and pancreatic gastrin cells in different clinical states. Gut, 13, 501-512.

Solcia, E., Capella, C., and Vassallo, G. (1969). Lead-haematoxylin as a stain for endocrine cells. Significance of staining and comparison with other selective methods. Histochemie, 20, 116-126.

Solcia, E., Vassallo, G., and Capella, C. (1968). Selective staining of endocrine cells by basic dyes after acid hydrolysis. Stain Technol., 43, 257-263.

Takaya, K. (1970). A new fluorescent stain with o-phthalaldehyde for A cells of the pancreatic islets. J. Histochem. Cytochem., 18, 178-186.

Temperley, J. M., and Stagg, B. H. (1971). Bioassay and radioimmunoassay of plasma gastrin in a case of Zollinger-Ellison syndrome. Scand. J. Gastroent., 6, 735-738.

Terner, J. Y., Gurland, J., and Gaer, F. (1964). Phosphotungstic acidhematoxylin: spectrophotometry of the lake in solution and in stained tissue. Stain. Technol., 39, 141-153.

Zollinger, R. M., and Ellison, E. H. (1955). Primary peptic ulcerations of the jejunum associated with islet cell tumors of the pancreas. Ann. Surg., 142, 709-728.

\section{Addendum}

Further acid secretion tests were performed at nine months. The results were: basal acid output $2 \cdot 24$ m-equiv/hour; peak acid output to pentagastrin 4.14 m-equiv/hour. A Hollander insulin test showed a complete vagotomy. 